\title{
Şairin Gönlündeki Arzu: Dîvân Şiirinde Teşne
}

\author{
İlknur SISSNELİOĞLU ÖZER*
}

\section{$\ddot{O} z$}

Klasik Türk şiirinde şairler duygu dünyalarındaki yoğunluğu dile getirebilmek için birtakım benzetmelere ihtiyaç duymuşlardır. Hislerini ifadede ve tesiri artırmak için başvurulan bu benzetmeler ile geniş bir anlam dünyasının oluştuğu görülür. Bu anlam dünyasının kapıları aralandığında ise, köklü bir kültür birikimi bütün ayrıntılarıyla karşımızda durmaktadır. Bu, bir taraftan bir kelimenin referans dildeki anlamı üzerinden kurulan ilişkiyle kendini gösterirken diğer taraftan çeşitli söz ve anlam sanatlarıyla katmanlar hâlinde ortaya çıkar.

Bu makalede, susamak ve istemek gibi gündelik hayatın tam ortasından bir hissi ifade eden teşne kelimesinin klasik Türk şiirinde kullanım şekilleri ve bu kelime etrafında oluşturulmuş anlam dünyası üzerinde çalışılmıştır. Dîvân şiirinden çeşitli örnek beyitlerle, şairlerin bu kelimeye hangi anlamları yükledikleri, bu tâbiri kullanırken hangi kaynak ve tarihî hadiselere telmih yaptıkları ve kelimeye sözlüklerde bulunan anlamları dışında hangi mânâlar yükledikleri incelenmeye çalışılmıştır. Bu incelemeler gerçekleştirilirken şairlerin dîvânları ile sınırlı kalınmaya özen gösterilmiş ve çeşitli yüzyıllara ait 100'den fazla dîvân ele alınmıştır. Araştırma sonunda ortaya çıkan anlam zenginliği, dıştan içe doğru katmanlar hâlinde kendini göstermekte ve bu kelime etrafında dönen hem sosyal dünya ile hem de şairin iç dünyasındaki yansımalar ile doğru yönde bir orantı oluşturmaktadır.

Anahtar Kelimeler: Teşne, klasik Türk şiiri, divan, su, arzu.

\footnotetext{
* Doktora Öğrencisi, İstanbul Üniversitesi, Sosyal Bilimler Enstitüsü, Türkiyat Araştırmaları Anabilim Dalı, İstanbul, Türkiye. Elmek: ilknurozerr@gmail.com https://orcid.org/0000-0002-5852-761X
}

Geliş Tarihi / Received Date: 06.05.2020

Kabul Tarihi / Accepted Date: 28.07.2020 


\title{
Desire in The Heart of The Poet: Tesne in Divan Poetry
}

\begin{abstract}
In classical Turkish poetry, poets needed some images so as to express the intensity of their emotional inner worlds. With these images which are used to express their feelings and increase the impact, it is seen that a wide world of meaning has been composed. When the doors of this world of meaning are opened, a deep rooted cultural richness stands before us in all its details. This manifests itself on the one hand with the relationship established on the meaning of a world in the reference language, and on the other hand, it occurs in layers with various figures of speech and meaning.

In this article, the ways of using the word 'tesne' which expresses a feeling from the middle of everyday life such as thirst and desire in classical Turkish poetry and the semantic world created around this word has been studied. With the various couplets from Divan poetry, it was tried to analyze what meanings the poets attributed to this word, which sources and events they used when using this phrase, and what meanings they added to the word except their dictionary meanings. While these investigations are being conducted, it was paid attention to be limited to Divans of the poets and more than 100 Divans of various centuries have been discussed. The richness of meaning that emerged at the end of the research manifests itself in layers from outside to inside and forms a direct proportion with the reflections in both the social world and the inner world of the poet.
\end{abstract}

Keywords: Tesne, classical Turkish Poetry, divan, water, desire. 


\section{Extended Summary}

The semantic world, established with imagery in classical Turkish poetry, has a wide range of richness and usage. This imagery is sometimes created through metaphors, sometimes through a network of relationships based on the first meanings of words. In order to understand this, it is necessary to absorb both the sources that nourish the culture and the meanings that the poets of the divan put into words.

The aim of the study is to examine the areas of usage of the term 'tesne' in divan poetry in the dimension of a nested meaning frame that goes from general to specific. Thus, the metaphors and citations made by the poets in this simple word will be an extra example to the depth of the poetry of divan.

In the writing stage of the study, a choice was made among those who expressed the most out of the couplets detected. The poems, which include the word 'tesne', were examined not only on the basis of couplet, but also by examining the type of poetry, the meaning is tried to be revealed in a healthier way, and thus the result shows that the meaning of this word was enriched. During the research phase, it was only limited to the divans; literary genres such as mesnevi and maâkıbnâme were excluded. In the article, the equivalents of the word 'tesne' in Turkish and Persian dictionaries were first given, and then the worlds of meaning of poets around this word were examined in a sequence from general to specific. Finally, with some numerical data, the frequency and forms of the use of this word were revealed.

As a Persian word, tesne is used to mean feeling thirsty, thirst and a strong feeling of wanting something, defined in the dictionaries. As a metaphor, the expression of the fire of hearts opens the doors of a very rich world of meaning to us. In addition to the longing for the lover that burns heart, this concept was frequently used in the religious literature.

In the first part of the study, the equivalents of the word "tesne" in various dictionaries were determined and a comparison was made. Although 
dictionaries have almost close meanings, it can be seen that figurative meanings also exist in the glossaries of terms. Then, in order to reveal the area of usage and purpose of this word, the first meaning of which is thirst, it was tried to reveal its connection with "tesne" in a more specific way by briefly emphasizing how water is used in classical Turkish poetry.

Ab-1 Hayat / Hizır / Iskender Relationship: As one of the richest motives of the divan poetry, âb-1 Hayat revives the dead, rejuvenates the old, heals the sick, and the living being survives by drinking from this water in many parables and legends from past to present. The immortality water, we mentioned has reflected on the literature countlessly.

Disease / Thirst / Dryness Relationship: In couplets, it is encountered as parched with thirst; the patient's suffering from thirst and becoming heated.

Heart / Union / Separation / Desire Relationship: In our classical poetry, the word tesne indicates the word that is one of the most appropriate forms of the expression of aspects of heart, desires, and complaints. For this reason, in this part of the study, the ways of expressing the descriptions of the heart and delusions in the heart were examined.

The Relationship Established with the Lethal Look of the Lover: Lovers who desire the lover's dagger, that is, the look of the lover, although they suffer with the lethality of this look, they come alive. For this reason, a glimpse of the beloved is a water-filled drink for them.

The Relationship Established with Islamic Terminology: Considering the whole of the divan poetry, if the probability of not having religious conceptions is not possible, it is already not possible for the term "tesna" that we have examined to be far from this world of meaning. In the religious field, the meanings of this word were formed generally around the words as "tawhid / mercy / tasavvuf”, "Hazrat Prophet”, “ Kabe ”, “Judgment Day ”, “Ahl al-Bayt / Karbala ", "Hazrat Yusuf".

The Relationship Established with Death: The inevitability of the death, and the fact that it will take place at the time that Allah commanded, was frequently used in divan poetry with the frames of various meanings. It 
is expressed that the thirst of the death is not ending as it is shaped around the word tesne, and it is thirsty to take new lives without stopping.

The Relationship Established Through the Districts: The association of the word 'tesne' with the towns has been realized at distant angles. This expression, which is used for purposes such as praising a town and complaining about its drought, was frequently used in the poems.

The desire of Inhuman Beings: In our classical poetry, longing, wanting and thirst are not only for individuals but also for inanimate objects. A rich vocabulary was created in poems by adding many objects to the circulation around this world of meaning which is based on meaning, composed with literary arts such as hüsn-i ta'lil and personification.

The Relationship Established with the Field of Inscription: In our divan poetry, this term was not only limited to expressing the desire of people but also became a means of expressing views of the poets in the field of inscription.

As a result, the word "tesne" expresses a feeling such as thirst and desire in the middle of everyday life. Poets used this word by associating it with many historical, legendary, literary and religious fields, and they were inspired by the events and concepts which were related to them. While preparing the article, we tried to reach a conclusion by analyzing these meanings expressed by the poets in open or implicit forms, and to reveal the world of meaning created around this word in the widest and healthiest way. In this context, it was determined that, apart from their meanings in the dictionaries, the term "tesne-dil" was used in the sense of feeling of immense sadness by keeping the heart away from the things that would cheer the heart up.

Some concepts such as husk-leb, atsan, tesne, which express "thirst" were used in the poetry of divan. However, among them, the term "tesne", which metaphorically meets some meanings with thirst, is the subject of our article and the semantic world built around this expression was tried to be enlightened.

During the study, 111 different poets who used the word "tesne" in their poems and a total of 1225 couplets belonging to these poets were identified. In addition, 13 poems, in which the word "tesne" was used as a redif, were 
encountered. The poets who use the word "tesne" in their poems were identified as Ahmedî, Gelibolulu Mustafa Âlî, Kadı Burhaneddin and Kâtibzâde Sâkıb respectively. Although it has been determined that the word "tesne" has never been used in the divan of some poets, there have been also significant numerical differences in the ones used. 


\section{Giriş}

Klasik Türk şiirinde çok yaygın kullanılan bazı kelime ve terkiplerin çoğu zaman bilinen anlamı ile kullanılmasının yanında, referans dilinde olan ve bugün dilimizde kaybolmuş anlamları ile kullanıldığına, yapılan pek çok araştırma ile tanıklık etmekteyiz. Zaman zaman şair, gerek söz gerekse anlam sanatlarını kullanarak kelimenin birkaç anlamını bir arada kullanmış, bu veçhile sözüne derin bir anlam dünyasını sığdırmıştır. Mânâ ve söyleyişteki bu derinliğe vâkıf olabilmek için edebî sanatları etkili biçimde ele alarak ve dahası klasik şiirimizin beslendiği kaynaklara hâkim olarak çözümlemeler yapmak yerinde olur.

"Dîvân edebiyat1, mücerret mefhumlar ve mazmunlarla doludur. Böyle olmakla beraber, bu mücerret dediğimiz mefhumlar ve mazmunlar, o devre ait akidelere, bilgilere ve kanaatlere telmih ve işaret ediyor.” (Levend 1984: 7) Çalışmamızın konusu olan teşne kelimesinin, sözlüklerde bulunan anlamlarının yanında klasik şiirimizin beslendiği kaynaklar dikkate alınarak incelendiğinde, iç içe geçmiş birçok anlam dünyasıyla bir arada kullanıldığı görülmektedir. Susamak ve istemek gibi gündelik hayatın tam ortasında bir hissi ifade eden bu kelime tarihî, efsanevî, edebî ve dinî birçok saha ile ilişkilendirilerek, ilgili bulunduğu olay ve mefhumlardan mülhem kullanılmıştır. Makaleyi hazırlarken şairlerin açık veya örtülü biçimlerde ifade ettikleri bu anlamları çözümleyerek bir sonuca ulaşmaya, en geniş ve sağlıklı biçimde bu kelimenin etrafında oluşturulmuş mânâ dünyasını ortaya koymaya çalıştık.

\section{Teşne Hakkında}

Teşne mefhumunun dîvân şiirinde hatırı sayılır bir zenginlik içerisinde kullanıldığı tespit edilmiştir. Sözünü ettiğimiz bu anlam zenginliğinin dıştan içe doğru bir katman şeklinde ifade edilmesi, bu kelime etrafinda dönen hem sosyal hem de şairin iç dünyasındaki yansımalar ile doğru orantılıdır.

Farsça bir kelime olan teşne hakkında çeşitli sözlüklerde yer alan anlam ve kullanım şekilleri şöyledir: 
Osmanlı Tarih Deyimleri ve Terimleri Sözlüğ̈̈: "Teşne: Farsça susuz, susamış demek olan bu tâbir mecaz yoluyla müştak, heveskâr yerinde kullanılır. Bundan pek ziyade susamış, dudağı kurumuş demek olan teşne-leb, istekli mânâsına gelen teşne-dil ve daha bazı mürekkep sıfatlarla da meydana getirilirdi." (Pakalın 1993: 477)

Ferheng-i Ziya: "Teşne: Susamış, susak. Teşne-dil: İstekli, iştiyaklı. Teşne-ciğer de bu mânâyadır. Teşne-i âbzâ: İstiska hastalığına tutulan kimse.” (Şükun 1996: 589)

Persian-English Dictionary: "Teşne: Hançer, kılıç. Susamış, susuzluğa kavuşturulmuş; istekli, açgözlü, doyumsuz. Teşne-şuden: Susamış olmak. Teşne-mândan: Sıkıntılı olmak, kederli olmak. Teşne-eşk: Gözyaşı dökülmesinde doyumsuz. Teşne-ciğer, Teşne-dil: susamış, arzulanan; arzu, dilek. Teşneçeşm: Susayan, istekli gözleri olan. Teşne-hûn: Kana susamış. Teşne-kâm: Kuru damaklı, susayan. Teşne-leb: Susuz, kavrulmuş dudaklı. Teşne-lebî: Susuzluk.” (Steingass 1998: 303)

Lehçe-i Osmânî: "Teşne: Susamış, arzukeş. Teşnegân: Heveskârân.” (Ahmet Vefik Paşa 2000: 859)

Tasavvuf Terimleri Sözlüğ̈̈: "Teşne: 1. Susuz, atşan, hareretli ve ateşli. 2. İlâhî Cemâl'i özleme sebebiyle aşığın yanık tutuşması.” (Uludağ 2001: 355)

Tasavvuf Terimleri ve Deyimleri Sözlüğü: "Teşne: Farsça susamış demektir. Hakk'ın cemâlinin özlemiyle yanıp tutuşanlara teşne denir." (Cebecioğlu 2005: 656)

Burhân-ı Kâtı: "Teşne-i çîzî bûden: Her şeye râkıb ve müştak olmaktan kinayettir. Teşne-ciğgr: Kemâliyle öğsemek ve özlemekten ve fart-1 iştiyâktan kinâyedir. Teşne-dil: teşne-ciğer mânâsınadır ki zikrolundu.” (Mütercim Âsım Efendi 2009: 772)

Kâmûs-i Türkî: "Teşne: c. Teşnegân. 1. Susamış, susuz, atşân. 2. mec. Pek heveskâr ve arzukeş. Teşnegân-ı maarif: Zaten kendisi teşne. Teşne-dil: Can u yürekten arzukeş. Teşne-leb: Dudağı kurumuş, pek susamış." (Şemseddin Sâmî: 2009: 408) 


\section{Dîvân Şiirinde Su}

Teşne ve su mefhumlarının birbirleriyle neredeyse ayrılmaz bir bütün şeklinde bulunmasından ve teşnenin sözlüklerdeki anlamlarından da yola çıkarak dîvân şiirinde öncelikle su üzerinde kısaca durmak gereklidir. Su, nasıl hayatın temel kaynağı ise dîvân şiirinin de ilham aldığı temel olgulardan biridir. Öte yandan Kur'ân-1 Kerîm'de çeşitli vesilelerle sudan bahseden âyetler bulunması ${ }^{1}$, Cennet ırmakları, bazı peygamber kıssalarında suyun yer alış biçimleri (Hz. Musa'nın bebekken suya birakılması, suyu ikiye yarması, Nuh tûfanı, Hz. Yûnus'un sular içine atılması), suyun arındırıcı özelliği, Anâsır-1 Erbaa'dan biri oluşu, canlılık kaynağı olması, insanın bir su damlasından yaratılması şairler tarafından suya verilen önemin sebepleri arasındadır.

Dîvân şiirindeyse su hem sevgilinin hem âşığın özelliklerine işaret ettiği gibi dinî mefhumlarda da son derece yüksek seviyede kullanılmıştır. Münacatlarda, Hz. Peygamber'i konu edinen na't-1 Nebîlerde, diğer peygamberleri konu edinen şiirlerde, Hz. Hüseyin ve Kerbelâ konulu mersiyelerde su temasının sıkça işlenmiş olduğunu görmekteyiz. Öte yandan hayatın böylesi temel bir kaynağı olan suyun mecazların ardından çıkarak kendini gösterdiği şiirler de vardır. Bunlara en belirgin örnek olarak çeşme inşaları için yazılmış tarih şiirlerini gösterebiliriz.

Suyun bu denli temel kaynak olduğu bir kültür ve edebiyatın ürünlerinde suya duyulan ihtiyaç ve arzu ile çeşitli vesilelerle yaşanan susuzluk hâlinin işlenmesi kaçınılmazdır. Dîvân şiirinde susuzluğu ifade edecek huşk-leb, atşân, teşne gibi bazı kavramlar kullanılmıştır. Ancak bunlar içerisinde susuzlukla birlikte mecazî açıdan da birtakım mânâları karşılayacak olan teşne tâbiri makalemizin konusu olup bu tâbir etrafında kurulan anlam dünyaları aydınlatılmaya çalışılacaktır.

\section{Dîvân Şiirinde Teşne}

Çalışma şairlerin sadece dîvânları ile sınırlandırılmış, diğer nazım türleri kapsam dışı bırakılmıştır. Yapılan araştırma neticesinde dîvânında teşne kelimesini kullanan 111 şair ve bu şairlere ait toplam 1225 beyit tespit edilmiştir. Ayrıca

1 (Bakara/22-60, En'âm/99, A'raf/57-160, Hicr/22, Nahl/10-65, Mü'minûn/18, Furkân/48-54, Rûm/24, Zümer/21, Mülk/30, Vakıa/68-69) 
teşne kelimesinin redif olarak kullanıldığı 13 adet şiire rastlanmıştır. Şiirlerinde teşne kelimesini en çok kullanan şairler sırasıyla Ahmedî (v. 1412), Gelibolulu Mustafa Âlî (v. 1600), Kadı Burhaneddin (v. 1398) ve Kâtibzâde Sâkıb (v. 1717?) olarak tespit edilmiştir.

14. yüzyıldan taradığımız Ahmedî ve Kadı Burhaneddin dîvânlarında tespit edebildiğimiz şekliyle Ahmedî dîvânında 66, Kadı Burhaneddin'de ise 54 yerde teşne kelimesi kullanılmıştır. 15. yüzyıldan ise inceleyebildiğimiz 15 adet dîvân içerisinde en fazla bu kelimeyi kullanan şair, 29 adet ile Şeyhî'dir (v. 1429'dan sonra). Bu yüzyılda Şeyhî’yi Karamanlı Aynî (v. 1490'dan sonra) ve Hamdullah Hamdî (v. 1503) takip etmektedir. Karamanlı Aynî’de 11 ve Hamdullah Hamdî dîvânında ise 9 yerde teşne kelimesine rastlanmıştır. Avnî mahlaslı Fatih Sultan Mehmed'in (1444-1446, 1451-1481) dîvânında ise teşne kelimesine hiç rastlanmamıştır. ${ }^{2}$ 16. yüzyıla geldiğimizde, ilk sırada Gelibolulu Mustafa Âlî bulunmaktadır. Şairin dîvânında 59 yerde bu kelimenin geçtiği tespit edilmiştir. Gelibolulu Mustafa Âlî’'den sonra Ahmed-i Ridvân'ın (v. 1528-1538 arası) dîvânında 34, Münîrî'nin (v. 1520?) dîvânında ise 28 yerde teşne kelimesine rastlanmıştır. Bu yüzyılda Âşık Çelebi (v. 1572) ve Figânî’nin (v. 1532) dîvânlarında ise teşne kelimesine hiç rastlanmamıştır. ${ }^{3} 17$. yüzyılda incelediğimiz şairler içinde Kâtibzâde Sâkıb, dîvânında 52 yerde teşne kelimesini kullanarak bu kelimeye en sık başvuran şairimizdir. Onun ardından Ahmed-i Nâmî’nin (v. 1673) dîvânında 25, Kâmî’nin (v. 1724) dîvânında ise 24 yerde teşne kelimesi tespit edilmiştir. İncelenen dîvânlar arasında Sunullah Gaybî (v. 1676'dan sonra) dîvânında teşne kelimesine rastlanmamıştır. ${ }^{4}$ 18. yüzyılda dîvânında teşne kelimesini 33 kez kullanmış olan Sâkıb Dede (v. 1735) en sık kullanan şair olarak karşımıza çıkmıştır. Bu yüzyılda taradığımız dîvânlar içerisinde Tırsî’nin (v. 1766?) dîvânında teşne kelimesine hiç rastlanılmamıştır. ${ }^{5}$ 19. yüzyıla geldiğimizde ise, dîvânında

2 15. yüzyılda dîvânları taranan diğer şairler: Adnî Mahmud Paşa(2), Şevkî(8), Ta'cizâde Ca'fer Çelebi(3), Hakîkî(8), Dede Ömer Rûşenî(1), Cemâlî(6), Mesîhî(3), Karamanlı Nizâmî(4) ve Necâtî Bey(8).

3 16. yüzyılda dîvânları taranan diğer şairler: Âhî(1), Amrî(1), Bâkî(21), Bursalı Rahmî(3), Cenâbî(3), Edirneli Nazmî(24), Emrî(6), Filibeli Vecdî(6), Fuzûlî(8), Gelibolulu Sun'î(1), Hayâlî Bey(13), Hecrî(2), Helâkî(3), Kalkandelenli Mu'îdî(10), Me'âlî(2), Mihrî Hatun(10), Mostarlı Ziyâî(12), Nev'î(20), Rahîmî(10), Ravzî(23), Revânî(5), Şâhî(3), Sehâbî(4), Selanikli Meşhûrî(7), Selîkî(1), Şem’î(6), Süheylî(3), Taşlıcalı Yahyâ(2), Üsküplü İshak Çelebi(14), Vizeli Behiştî(9), Zâtî(9), Usûlî(2), Yakînî(6), Vusûlî(1), Celîlî(19).

4 17. yüzyılda dîvânları taranan diğer şairler: Nev'îzâde Atâyî(15), Vahyî(3), Ümmi Sinan(3), Tecellî(1), Nehcî(17), Mezâkî(10), Nâbî(19), Nâ'ilî̀-i Kadim(23), Nef'î(14), Nisârî(7), Fevzî(4), Şeyhülislam Bahâyî(2), Şeyhülislam Yahyâ(13), Şehrî(11), Beyânî(21), Bosnalı Âsım(5), Azmizâde Hâletî(16), Bahtî(1).

5 18. yüzyılda dîvânları taranan diğer şairler: Kânî(10), Şeyhülislam Es'ad(10), Mekkî(1), Sa'id Giray(6), Nedîm(7), 
teşne kelimesini en sık kullanan şair olarak Nigârî (v. 1886) tespit edilebilmiştir. ${ }^{6}$ Nigârî’nin dîvânında 35 yerde kelime tespit edilmiştir.

Şairler teşneyi redif olarak da kullanmışlardır. Gündelik hayatın her noktasına temas edebilecek ve bu denli sık başvurulan bir benzetme öğesi olan teşnenin redif olarak kullanımının sayıca çok az olduğu tespit edilmiştir. Taranan dîvânlarda 4 gazel ile teşneyi redif olarak en çok kullanan isim Kadı Burhaneddin'dir. Onun dışında Şeyhî’nin 2 gazeli; Bakî (v. 1600), Ahmed-i Rıdvan, Gelibolulu Mustafa Âlî, Şeyhülislam Yahyâ (v. 1643), Nev'îzâde Atâyî (v. 1635) ve Kâmî'nin birer gazeli ve Sâkıb Dede'nin de bir rubâisi bulunmaktadır. ${ }^{7}$

Öte taraftan teşne kelimesi şiirlerde tek başına yer alabildiği gibi birlikte kullanıldığı bazı terkipler şunlardır: teşne-dil, dil-teşnegî, teşne-leb, leb-teşnegî, leb-teşne-ter, teşne-i âb-l zülâl, teşne-i zülâl, teşne-ciğer, teşne-i şevk, teşne-i âb-l safâ, teşne-zebân, teşne-i gam, teşne-i ihsan, teşne-i mey, teşne-hâl, teşnehûn, teşne-i aşk, teşne-yâb, teşne-ter, pür-teşne, teşnegî, teşne-cân, teşne-vâr, be-cân-teşne, teşnegî-çîn, teşne-terîn, kavî-teşne, cihân-teşne, teşne-hâl, teşneender-teşne, teşne-kevser, teşne-kâm, leb-teşne-dil, teşne-hâtır, teşne-dâr, teşne-i mâu'l-’ineb, teşne-i âb, teşne-i hişm, teşne-i muhabbet, teşne-i ser-çeşme-i ' $y y s ̧$, teşnegân-ı ma'rifet, teşne-i zevk, teşnegîl-i haşr, teşne-i dîdâr, teşnegân-ı Kerbelâ.

\section{Teşne ile Kurulan Anlam İlişkileri}

Genel hatlarıyla teşne, "dîvân şiir ve nesrinde vahdet simgesi olan leb (dudak), dîdâr (cemâl, yüz) ve vuslat talebinde olan gönül ve âşığın sıfatı olarak kullanılmaktadır." (Zavotçu: 2018: 689)

Kelimenin birinci anlamı olarak “susuz”luğu karşılamasının yanında mecâzî olarak gönül yangınını ifade etmesi, bizlere son derece zengin bir anlam dünyasının kapılarını açmaktadır. Sevgiliye duyulan özlemin gönlü kor gibi yakması yanında bu mefhuma dinî literatürde de sıkça başvurulmuştur. Öncelikle Allah'1n rahmetine ve Hz. Muhammed (SAV)' in şefaatine muhtaciyetin bir ifade-

Nebzî(10), Muvakkitzâde Muhammed Pertev(15) Sıdkî(3), Arpaeminizâde Mustafa Sâmî(10), Haşmet(11), Diyarbakırlı Hâmî(4), Ecrî(15), Lebîb(6), Erzurumlu Zihnî(8), Esrar Dede(5), Sâfî(13), Feyzullah Nâfiz(20), Şeyh Gâlib(17).

6 19. yüzyılda dîvânları taranan diğer şairler: Şeref Hanım(15), Osman Şems Efendi(16), Bursalı İffet(8), Leylâ Hanım(5), Nûman Mâhir(4), Hersekli Ârif Hikmet Bey(1), Osman Nevres Bey(5).

7 Kadı Burhâneddin'in bir gazeli “teşnedür”, Bâkî’nin gazeli “teşnedür”, Şeyhülislam Yahyâ, Nev’îzâde Atâyî ve Kâmî’nin gazelleri ise "teşne-leb" rediflidir. 
si olarak karşımıza çıkan teşne tâbiri, bir alt katmanda Hz. Hızır'ın âb-1 hayâtı buluşu, Hz. Yûsuf'un kuyuya atılması ve Hz. Hüseyin'in Kerbelâ'da 10 gün susuz bırakıldıktan sonra şehit edilmesi gibi hadiselerle ihata edilmiştir.

Ayrıca teşne kelimesinin kitabet sahasında, insan dışı varlıkların hâllerini ifade etmede ve ecel, kıyamet günü gibi çeşitli şekillerde anlamlandırıldığı görülmüştür.

Bu çalışma yapılırken çeşitli yüzyıllardan 111 adet dîvân taranmış ve teşne kelimesinin etrafında dönen anlam dünyası tespit edilmeye çalışılmıştır. İçerisinde teşne geçen şiirler sadece beyit bazında değil şiirin türü de ele alınıp incelenerek anlam daha sağlıklı bir biçimde ortaya koyulmaya çalışılmış ve böylece bu kelimenin mânâ yönünün daha da zenginleştiği sonucuna ulaşılmıştır.

\section{1. Âb-ı Hayat/Hızır/İskender İlişkisi}

$\mathrm{Bu}$ tâbirin anlam dünyasında en geniş biçimde karşımıza çıkan mefhum tabii olarak âb-1 hayat olmuştur. Dîvân şiirinin en zengin motiflerinden biri olan âb-1 hayat ve onunla birlikte sıklıkla kullanılan âb-1 hayvân dirilik suyu, hayat çeşmesi, âb-1 câvidânî, âb-1 zindegânî gibi isimlerle ifade edilmiştir. Evvelden günümüze intikal eden birçok kıssa ve efsanede bu su ölüyü diriltir, ihtiyarı gençleştirir, hastaları iyileştirir, yaşayanlar ise bu sudan içerek ölümden kurtulur.

Kur'ân-1 Kerim'de Kehf Sûresi'nde anlatılan Hz. Musa ve Hızır'ın kıssalarında da âb-1 hayata temas vardır. Hz. Mûsâ bir gün kendisine buluşması emredilen kişiyi bulmak üzere arkadaşı ile yola koyulur. Buluşma yerleri "mecmau'lbahreyn" olarak adlandırılan iki denizin birleştiği yerdir. Bu yerde âb-1 hayat olduğu ise, Hz. Mûsâ'nın burasını tanıyabilmek için yanına azık olarak almış olduğu balıktan anlaşlacaktır. Nitekim bahsedilen yere gelindiğinde balık bir kayada iken dirilip suya atlamıştır. Bu durum Hz. Mûsâ’ya haber verilip kendisi de oraya gittiğinde aradığı kişinin orada olduğunu görür.

Edebiyatımızda ise âb-1 hayât, ilmî ve tasavvufî boyutlarının yanında birçok açıdan şairin merâmını dile getirecek çok yönlü bir argüman olmuş ve sıklıkla kullanılagelmiştir. Bu doğrultuda teşne tâbiri ile bir arada en sık kullanılan motiflerden biri olmuştur. “Âb-1 hayat, yani dirilik suyu Tuhfe-i Vehbî Şerhi'ne göre mahbûbun ağzı ve cân bağışlayan söz demektir. Şark edebiyatının en zengin mazmunlarından birini teşkil etmiştir.”(Onay 2014: 23) 
Mu'îdî (v. 1560-1568 arası), âb-1 hayâtın hastaları iyileştirmesinden dem vurmuş ve âb-1 hayât diyerek sevgilisine hitap etmiştir:

Mu'îdî haste- 'âşıdkur gamundan bagrı yanıkdur

Koma dil-teşne yazukdur yetiş iy âb-ı hayvânum (Kalkandelenli Mu'îdî, G:290/7)

Ahmedî her âb-1 hayât isteyenin onu bulamayacağını, dahası her susayanın içtiği suyun da âb-1 hayat olmasının mümkün olmayacağını söylemiştir:

Lebünün şavkl-la gonca n'ola dil-teng itdi-y-se

Kamu teşne-ciger olan bulur $m ı$ âb-ı hayvânı (Ahmedî: K:71/14)

Şair bir diğer beytinde ise sevgilisinin ağzını şekere benzetmiş ve hayat çeşmesinin, sevgilinin ağzına susamış olduğunu dile getirmiştir. Dolayısıyla âb-1 hayât herkes tarafindan aranıp istenen bir su olmakla birlikte, bu mucizevi suyun sevgilinin dudağını istemesi, bir başka mânâ ile ondan beslenmiş olması şiirlerde sıklıkla yer verilmiş bir anlatımdır:

Bir katresi-y-içün lebünün teşne-dil olup

Âb-ı hayât kendüyi hâk-i zemîn ider (Ahmedî: G: 167/5)

Şehnâme ile Ahmedî ve Ahmed-i Ridvân'ın İskendernâmelerinin ana örüntüsünde âb-1 hayât ile ilgili anlatılan hikâye de şiirlere sıklıkla konu olmuştur. Haşmetli ve kudretli bir hükümdar olan İskender-i Zülkarneyn âb-1 hayâtın varlığından haberdar olduktan sonra onu bulmaya karar verir. Hızır'1 da yanına alarak yolculuğa çıarlar. Birçok macera yaşayıp beldeler geçtikten sonra âb-1 hayâtın bulunduğu zulmet ülkesine varırlar. Burada İskender bir tarafa Hızır da diğer tarafa doğru gider. Hızır âb-1 hayâtı bulup içerek ebedî hayata kavuşur ancak İskender bulamaz ve bir müddet sonra da ölür. Bu hikâye şiirlere İskender'in kısmetsizliği ve susuz kalmışlığı ile yansımaktadır. Dolayısıyla bir şekilde sevgilisine ulaşamayan âşı, İskender'in, dirilik suyuna teşne kaldığı gibidir:

\section{Zulmet-i hicrânda kaldum teşne İskender gibi}

Leblerün ser-çeşme-i cân oldugindan bana ne (Yakînî: G: 182/5)

Bahsini ettiğimiz ölümsüzlük suyu literatüre sayısız şekilde aksetmiştir. Örneğin nâzil oluşuyla adeta ölü kalplere canlılık veren Kur'ân-1 Kerîm, şefaati ile müminler için adeta dirilik ve ferahlık kaynağı olmuş Hz. Muhammed (SAV), 
vahdet ve imanın timsali oluşuyla Kâbe âb-1 hayât şeklinde tasavvur edilirken şairler sevgiliyi veya methettikleri kişiyi de âb-1 hayâta benzetirler. Ayrıca şiirlerde, bu suyun zulmet ülkesinde bulunmasına da telmih yapılarak teşneliğin sadece suya değil onun etrafinda bulunan toprağa veya karanlığa karşı olduğu da görülmektedir:

Teşne-cigerdür ayagunun topragına cân

Kim bilür anda ki âb-ı hayâtun nişânı var (Ahmedî: G: 169/4)

\section{Hastalık/Susuzluk/Kuruluk İlişkisi}

Teşne kelimesinin, sözlüklerde birinci anlamı olan susuz, susamış şeklinde şiirlerde yer aldığı görülmektedir. Bu aynı zamanda susuzluktan kurumak, hastanın susuzluk çekmesi ve kişinin susuzluktan hararetlenmesi şeklinde de beyitlerde karşımıza çıkmaktadır.

Yakînî (v. 1568), aşkını susamış bir kişinin su içmemeye tövbe edememesine benzetmiştir:

'Aceb mi itmese 'âşı şarâbdan tevbe

İder mi teşne olan kimse âbdan tevbe (Yakînî: G: 177/1)

Bâkî ise, şu beytinde sevgilinin yanağına duyduğu hasretle hasta düştüğünü belirterek, hasta bir kişinin (özellikle geceleri) nasıl hararet ve susuzluk içerisinde kaldığından dem vurmaktadır:

'Ârizun hasreti bir 'ârızadur Bâkî'ye kim

Teşne-dil haste yatur iki gözi mâ gözedür (Bâkî: G: 67/7)

"Sevgilinin eliyle sunduğu aşk şerbeti âşığın teşneliğinin sebebi olarak ele alınır. Bu tasavvurda tatlının harâret verme özelliği önemli bir unsurdur."(Sefercioğlu 2001: 260)

İçürdi şerbet-i lşkl elinden gerçi Nev'ı̂'ye

Koyup ol cân tabîbi teşne vü bîmâr eğlendi (Nev'î: G: 511/5)

Erzurumlu Zihnî (v. 1796?) ise aşağıdaki beytini hastalıktan susamak remzi altında dinî bir yaklaşımla söylemiştir. Günahkârlık ve âsîliğin gönülleri kurutan bir hastalığa benzetildiği beyitte, kişiyi bu hastalıktan ancak Allah'ın rahmet suyu kurtarabilir. Bu su, günahkâr kişiye şifa olur: 
Dil-teşne âb-ı rahmete bîmâr-ı ma siyet

Reyyân eder hekîm-i şifâkâr-ı mağfiret (Erzurumlu Zihnî: G: 20/7)

Öte yandan Esrar Dede (v. 1796) sevgilinin, gönlündeki eski yaraları açmak için hançere benzeyen bakışını kullanmasını ve kurumuş yaralarına bir damla olsun su vermesini istemektedir. Kelimenin, susuzluktan kurumak anlamındaki kullanımı, bu beyitte yaranın kuruması şeklinde ifade edilmektedir:

Aç dâğ-ı köhnemi meded ey hançer-i nigâh

Leb-teşnegî-i zahmıma bir cür 'a âb ver (Esrar Dede: G: 55/6)

Teşne ifadesinin susamış mânâsıyla karşımıza en sık çıktığı alanlardan biri de çeşmelere yazılmış tarih manzumeleridir. Örneğin; Edirneli Nazmî’nin (v. 1559'dan sonra) Üsküdar'daki Rüstem Paşa Çeşmesi için yazmış olduğu tarih manzumesinde, susayıp bu çeşmeden su içenlerin dua etmesi istenmektedir:

Bundan âb içüp geçen dil-teşneler

İdeler cândan revân ana du'â (Edirneli Nazmî: T: 199/3)

Lebîb'in (v. 1768) Ali Paşa Çeşmesi için yazdığı tarihte ise çeşmenin bulunduğu muhitteki çarşı ve mescidin suya muhtaç olduğundan, Ali Paşa'nın buraya bir çeşme koyup susamışları ihya ettiğinden bahsedilmektedir:

Ahâlîsi bu sûk u mescidin muhtâc idi âba

Bu câya vaz' edip leb-teşnegânı eyledi ihyâ (Diyarbakırlı Lebîb: T: 30/7)

Öte taraftan oruçlu olan kişinin susamışlığı da mecaz yoluyla şiirlerde sıklıkla kullanılmıştır:

Itdigi cevre felek tâ'ib ü müstagfir olup

Oldı bir zâhid-i leb-teşne-i eyyâm-ı sıyâm (Bursalı İffet: K: 1/10)

\section{Gönül/Vuslat/Hicran/Arzu İlişkisi}

Türkçe kökenli olan ve sözlükte "İnsanın manevi varlığının ifadesi, inanç ve hislerimizin kaynağı, önüne geçilemeyen iç kuvveti; kalp, dil” (Doğan 2011: 619-620) olarak tanımlanan gönül kelimesi, klasik şiirimizde oldukça geniş bir anlam bütünü hâlinde karşımıza çıkmaktadır. Bu bütünü içine alacak biçimde gönlü, maddi ve manevi bütün duyguların tecelligâhı olarak tanımlayabiliriz.

İnsanın mücerret ve müşahhas bütün isteklerinin barınağı olan gönül ve yaşamın temel kaynağı olan suyun bir arada kullanılmamış olması düşünülemez. 
Klasik şiirimizde de gönlün hâllerini, arzularını, şikâyetlerini maksada en uygun ifade biçimlerinden biri olan teşne tâbiri karşılamaktadır. Bu sebeple çalışmanın bu kısmında, gönle dair sözlerin teşne ile bir arada ne çeşit anlamlar oluşturduğu incelenmiştir.

3.1. Ayrılık: Klasik şiirimizde, gönlü sevgilinin hasretiyle yanıp kebaba dönmüş ana tip Mecnûn'dur. Bâkî beytinde Mecnûn'u çölde teşne-dil bir hâlde tasvir etmektedir. Allah'a kavuşmayı arzulayan Mecnûn, ayrılı̆̆ın acısıyla ne yapacağını bilemeden, gönlü yanmış bir biçimde çöllerde dolaşırken ecel kadehi onu ölümsüzlük suyuna kandırır:

Bulup sakkâ-yı hicrân teşne-dil sahrada Mecnûnı

Ecel peymânesin sunmış hayât âbına kandurmış (Bâkî: G: 219/4)

Gönülden susamış, özlemiş veya gönlü hevesli âşıkları ifadede sıklıkla başvurulan teşne-dil terkibi, bazı beyitlerde her iki mânâyı da bir arada sunmuştur:

Dil teşne-i zülâl-i visâl-i hemîşedür

Ben cân-ı nâ-tüvân-ı ser-endâz-ı gamzeyim (Ahmed-i Nâmî: G: 289)

Arrẑิ-yı leb-i cânân ile öldüm gitdi

Teşneyem âteş-i hırmân ile öldüm gitdi (Rahimî: G: 345/1)

Nev’î (v. 1599) aşağıdaki beytinde gönlünün sevgilinin yüzünü görmeyi çok arzuladığından dem vurarak teşne olduğunu söylemektedir:

Visâle teşne diller gözler ol hatt-ı siyeh-fâmı

Hemân ol rûze-dâra döndiler kim ister ahşamı (Nev'î: G: 512/1)

3.2. Gönlün Tasviri: Teşne kelimesi ile gönlün bizâtihi kendisinin betimlendiği beyitler de bulunmaktadır. Bu kimi zaman bir dost meclisinin özlemiyle, kimi zaman şaraba duyulan istek ile kimi zaman da saadet arayışı ile vücuda gelmektedir:

O dildârun şarâb-ı vaslı kadrin bilmez illâ kim

Ola dil-teşne anun berr-i hicrinde 'ataşlarla (Edirneli Nazmî: G: 5470/3)

Zehr-i kahrı sunar bu dehr-i denî

Teşne-dil mâ 'il olsa cüllâba (Mostarlı Ziyâî: K: 10/6) 
Teşne-dil Edincikli Ravzî’nin aşağıdaki beytinde, hastalığa dûçar olmuş gönlü tasvir etmektedir. Hasta gönüller irfan meclisinde Ravzî’nin şiirleriyle devâ bulmaktadır. Öte yandan şiirin gönülleri coşturucu bir unsur olmasından hareketle, teşne-dil kelimesinin bu canlılıktan mahrum kalmış bir gönlü tasvir etmesi de mümkündür. Kelimenin bu anlamına sözlüklerde rastlanmamıştır.

Bezm-i 'irfân içre devr itmezdi ey Ravzî müdâm

Teşne-diller derdine olmasa eş'ârın 'ilâc (Edincikli Ravzî: G:152/5)

3.3. Arzu/İstek: Şairler teşne etrafında, gönüllerin düştüğü arzuları da betimlemişlerdir. Örneğin Kâmî, bir beytinde fâni dünyanın rengârenk nimetlerini arzulayan gönüllerden söz etmektedir:

Dil-teşne olan ni 'met-i elvân-ı cihâna

Görmez mi perîşâni-i evrâk-ı hazânı (Kâmî: G: 223/5)

Kâtibzâde Sâkıb'da ise tasavvufi boyutta gönlü zevke düşenleri görmekteyiz. Beyitte Allah'ın tecellilerini müşahede etmenin verdiği zevke padişahların bile gönlünün düştüğü ve bu arzunun kaynağının kanaat dağında, yani Kaf Dağı'nda olduğu anlatılmaktadır:

Ol zevk ki dil-teşnesidür şâhlar anun

Ser-çeşmesi kûhsâr-ı kanâ 'atde bulındı (Kâtibzâde Sâkıb: G: 585/2)

Mustafa Sâmi Bey'in (v. 1734) Şehit Ali Paşa için yazmış olduğu kasidesinde ise, isteklerin çölünde susuz kalmışlardan söz edilir:

Teşne-i deşt-i temennâya devâtundan olur

Mevc-der-mevc hurûş âb-ı revân-ı devlet (Arpaeminizâde Mustafa Sâmi: K: 14/7)

Rahîmî'de ise, sevgilinin dudağına susamanın, onu istemenin âb-1 hayâta susamaktan ve onu aramaktan daha büyük bir zahmet olduğu görülmektedir:

Hayli dem ben teşne-dil çekdüm leb-i cânân gamın

Çekmedüm ömrümde bir gün çeşme-i hayvân gamin (Rahîmî: G: 255/1)

\section{Sevgilinin Öldürücü Bakışı ile Kurulan İlişki}

Klasik Türk şiirinde sevgilinin bakışları keskin kılıca benzetilir. Onun bir bakışı bin âşı öldürür, âşıkların ise en büyük arzusu sevgilinin bakışı ile ölmektir. 
Âşığına sürekli cevr ü cefâ eden "sevgili onu adeta bu acılarla öldürmeye azmetmiş, âşı̆̆ın kanına susamıştır. Ayrıca şiirlerde çifte su verilmiş çelikten yapılan, keskin ve parlak oluşuyla öne çıkan kılıç, Farş̧ada "su veren hizmetçi" (Steingass: 1998: 5) mânâsıyla da karşılık bulan âbdâr" kelimesi ile kullanılmış ve bu özelliğinden dolayı teşne tâbiriyle bir arada sıklıkla karşımıza çıkmıştır:

Agzuma alsam eger yâkût-ı rümmânî gibi

Eyleye ben teşneyi sîr-âb o la 'l-i âb-dâr (Nev'îzâde Atâyî: G: 79/3)

Sevgilinin hançerini, yani bakışını arzu eden âşıklar bu bakışın öldürücülügü ile her ne kadar acı çekseler de hayat bulurlar. Bu sebeple sevgilinin bir anlık bakışı onlar için cana can katan bir içim su yerine geçer:

Gördiler hançerünün zahmı virür câna hayât

'Âşık-ı teşne-cigerler bir içim su didiler (Bâkî: G: 184/5)

Diğer taraftan sevgili, âşığa yüz vermeyecek ve onun, aşkından düştüğü hâllere acımayacak kadar da zâlimdir. Sevgilinin yüzüne, öldürücü bakışına, dudağına, bulunduğu yere, kısacası sevgili ile ilgili her şeye istekli olan ise âşıktır. Ancak bazı beyitlerde sevgili, âşıklarının kanına susamıştır; onları bakışlarıyla öldürmek ister. Bu hâliyle sevgili zaman zaman kılıcını Müslümanların üzerine savuran kâfir gibidir:

Teşne-dildür şu kadar hûn-ı Müselmân üzre

Tîg-i kâfir gibi ol gamze-i bürrân ditrer (Bâkî: G:137/4)

Kanuma teşneyidi şemşîüün

Kan içe içe kandı hey kâfir (Edincikli Ravzî: G: 269/2)

İshâk Çelebi'nin (v. 1538) şu beytinde ise, sevgilinin aşığın kanına teşne oluşunun başka bir türlüsü karşımıza çıkıyor. Sevgili âşığın kanını, başkalarına buse vererek akitıyor:

Bizi öldürmek içim gayrılara bûse virür

Teşnedür ol sanemün la l-i lebi kanımuza (Üsküplü İshak Çelebi: G: 252/3)

Sevgilinin âşığın kanına susamış olmasına beyitlerde mecaz yoluyla da yer verilmiştir. Sevgilinin bakışı âşığın kanına susayan, parlak bir kılıca benzetildiği gibi parlak bir kılıç keskinliğini de hatırlatmaktadır: 
Gamzeler mahmûr kana çeşm-i şehlâ teşne-leb

Hep anunçün katlüme tîg-i mücellâ teşne-leb (Nev'îzâde Atayî: G: 14/1)

\section{5. İslâmî Terminoloji ile Kurulan İlişki}

Kesrette vahdeti, maddede mânâyı, kısacası gözünü çevirdiği her yönde Allah'ın tecellisini gören Hak âşıkları için şiir, merâmı anlatmada en etkili yol olmuştur. Mecaz, telmih ve teşbihlerle bezenmiş tasavvufî şiir anlayışı klasik Osmanlı şiirinin de ayrılmaz bir parçası hâline gelmiştir. Bu hazır tasavvufî terminolojiyi kullanarak şiir söyleyen şairler olduğu gibi, klasik şiirimizin sanatlı söyleyişinden istifade eden Hak âşıları da duygularını dîvân şiirinin malzemeleri ile dile getirmişlerdir.

Dîvân şiirinin bütününü göz önüne aldığımızda dinî mefhumların bulunmaması ihtimali nasıl mümkün değilse, incelediğimiz teşne tâbirinin de bu mefhumlardan uzak olması elbette mümkün değildir. Bu tâbirin dinî yönden incelenmesinde, genel anlam çerçevelerinin yanı sıra müstakil olarak özele doğru daralan bir çember de göze çarpmaktadır.

5.1. Tevhid/Rahmet/Tasavvuf: "Eski edebiyatımızda tasavvufî edânın çok bedii bir kıymeti vardı. Edebî sanatlara meclûp olan şairler bütün fikir ve akîdeleri birer sembolle ifade eden tasavvuftan bu hususta çok istifade etmişlerdir." (Levend 1984: 44) Yapılan incelemelerde, teşne kelimesinin Allah'ın cemâlini, lütfunu ve rahmetini dilemek mânâlarında sıkça kullanılmış olduğu görülmüştür.

Kâtibzâde Sâkıb, Allah'ın merhamet çeşmesi böylesi leziz olmasaydı, gönlünün günahı bu denli arzulamayacağını söylemiştir. Aslında teşne olunan, arzulanan şey bu beyitte günah değil, Allah'ın rahmetidir:

Çâk olmazdı leb-i dil-teşnegân-ı ma 'siyet

Olmasa tâ ol kadar ser-çeşme-i gufrân lezîz (Kâtibzâde Sâkıb: G: 80/2)

Nâ’ilî (v. 1666) de talep ırmağına susayan ve sürekli talep eden kişi mahrumiyet semtine düşer; Hakk'ı aramayı talep eden ve bu yolda hararetle giden kişi ise hayret çölünde kalır, hayret makamını aşamaz, demiştir. Bu beyitte teşne-leb dünyada istekleri bitmeyen, bitmedikçe de susuzluğu geçmeyen kişi için kullanılmıştır: 
Semt-i hırmâna düşer teşne-leb-i cûy-i taleb

Tîh-i hayretde kalır germ-rev-i sûy-i taleb (Nâ'ilî-i Kadîm: G: 12/1)

Nigârî'nin aşağıdaki beytinde ise leb-teşne tâbiri ceza çölünde dudakları kurumuş bir şekilde susuz kalmak ve aynı zamanda dualarına cevap bulamamış birinin çöllerde susuz ve kararsız yürümesi şeklinde anlam bulmaktadır:

Leb-teşne-i sahrâ-yl cezâ itme İlâhî

Kesme ümîdim sâkî-i Kevser'den ayırma (Nigârî: G: 575/5)

Nigârî ayrıca teşne kimseleri, başlangıcı olmayan ezelî hakikati, Allah’tan ilahi aşkın şarabını isteyenler olarak tasvir etmektedir:

Tâlib-i bâde-i engûr degüldür Hak'dan

Teşnegân-ı ezelî mey-i kadîm isterler (Nigârî: G: 269/5)

Bu dünyada yaşamış oldukları ayrılıktan gönlü yanıp kurumuş olanlar da Allah'a kavuştuklarında arzularından yanmış gönüllerini vuslat suyuna kandıracaklardır:

Şevk yazısında yandılar zülâl-i vasl içün

Teşne-diller gözlerinden dökdi Ceyhûn u Aras (Şeyhî: K: II/7)

Gelibolulu Mustafa Âlî’nin XIV. XV. yüzyıllarda yaşamış olan Kalenderî şeyhi Şücâüddîn-i Velî için söylemiş olduğu aşağıdaki beyitte ondan meded umduğu, himmetini arzuladığı ve onun tarikatını içimi hoş, uğurlu bir suya benzeterek kendisinin de bu suya teşne olduğunu görmekteyiz:

Ey pîşvâ-yı râh-ı țarîkat meded meded

Devlet zülâlin eyleme ben teşneye serâb (Gelibolulu Mustafa Ali: K: 89/18)

Nâbî (v. 1712), Hz. Mevlânâ (v. 1273) türbesinin tamiri için kaleme aldığı tarih şiirinde, aşka susamış olanların Hz. Mevlânâ'nın sözlerinden âb-1 hayât içmişçesine suya, onun feyizlerine kandığını söylemektedir:

Her mevci misra 'indan olur teşnegân-ı 'aşk

Âb-ı hayât nûş idicek denlü mürtevî (Nâbî: T: 52/8)

Kütahya Mevlevîhânesi şeyhi Sâkıb Dede'nin Hz. Mevlânâ için kaleme aldığı naatında ise, Hz. Pîr'in, aşk ehlinin susuz gönlünü lütuf dalgaları ile şâd ettiği söylenmektedir: 
Mevc-i lutfun teşne-cân-ı ehl-i 'ışkı şâd ider

Mâh ü mâhî yek-zebân olmış kemâlün yâd ider (Sâkıb Dede: Müs: 1/3-3)

5. 2. Hz. Peygamber: "Dîvân edebiyatında bilhassa Hz. Peygamber ve Çâryâr Hazarâtı ile Cenâb-1 Ali vasfında yazılan" (Tâhirü'l-Mevlevî 1994: 113) manzumelere na't adı verilmektedir. Dîvânlarda teşne Hz. Peygamber'in şefaatine nail olmayı dilemek, cihânın onun nurunu arzulaması, Resulullah'ın lütfunun insana hayat bahşedici olması, onun mübarek yüzüne duyulan iştiyak gibi pek çok mânâda karşımıza çıkmaktadır.

Ahmedî âb-1 hayât çeşmesinin Hz. Muhammed (SAV)'in varlı̆̆ında kendini yok etmesinden ve herkesin susadığı bu can çeşmesinin kalbinin de Hz. Muhammed (SAV)'e susadığından bahsetmektedir:

Göreli la 'lini ki eridür âb-ı kevseri

Teşne-dil oldı çeşme-i hayvân Muhammed'e (Ahmedî: K: 3/3)

Hz. Peygamber'in cemâlini gönülden istemek ve bu aşk ile gönlün yanmas1 da şiirlerde teşne kelimesi ile yerini almıştır:

Hudâ bilir ki gönül teşnedir cemâlin için

Zülâl-i tal'at-i pâkinle eyle sen irvâ (Hammâmîzâde İhsan: K: 1/53)

Mahşer günü ümmetin Hz. Peygamber' in şefaatini dilemesini ise Said Giray (v. 1728) ramazaniyyesinde dile getirmiştir:

Kandurur ümmet-i dil-teşneni rûz-ı mahşer

Eylesen lutfunıla âb-l şefâ 'at cereyân (Said Giray: K: 3/33)

Ahmed-i Nâmî'de cümle cihânın âlemlere rahmet olarak gönderilen Hz. Muhammed (SAV) ile nûra gark olsa da onun feyzine doyamayacağı, her daim gönülden istekli olacağı anlaşılmaktadır:

Nâmîââa gark-ı nûr iken bu zerrât-ı cihân

Feyz-i nûra yine hep dil-teşne olmış bî-nizâ' (Ahmed-i Nâmî: G: 55/5)

Âlemlere rahmet olan Peygamber Efendimizin şefkati, isyan çöllerinde kalmış susuzlara hayat suyu olur, onun tükenmez feyzi hayat artırır:

Hayât-efzâ olur dil-teşne-yi sahrâ-yl 'isyâna

Zülâl-i şefḳatin āb-ı bekâdır yâ Resûlallâh (Sünbülzâde Vehbî: K: 2/4) 
Mustafa Sâmî'nin na’tında ise, Hz. Peygamber'in aşkıyla gönlü yananların âhları gecenin rengine benzetiliyor:

Şebi hem-reng-i âh-l teşnegân-ı el-'ataş-gûyân

Sabâhı tûde-i hâkister-i güm-kerde-râhânî (Arpaeminizâde Mustafa Sâmî: $\mathrm{K}: 2 / 9)$

5. 3. Kâbe: Klasik Türk şiirinde Kâbe etrafında oldukça geniş bir anlam dünyası oluşturulmuş; sevgilinin yüzü, mahallesi, âşı̆̆ın gönlü Kâbe’ye benzetilmiştir. Bunun haricinde müstakil olarak Kâbe hakkında, Kâbenâme adıyla anılan eserler de kaleme alınmıştır.

Yeryüzünde inşa edilmiş ilk mâbed ${ }^{8}$, bütün Müslümanların kıblesi, Allah'ın evi olan Kâbe klasik şiirimizin de vazgeçilmez bir mazmunu olmuştur. Ahmed-i Nâmî, Kâbe’yi methettiği kasidesinde dil-teşne tâbiri ile Kâbe’yi özleyen, onu görmeye gönülden istek duyan kişileri kastetmiştir:

Hoşâ tavâf-ı harem-gâh-ı emr-i Rabbânî

Ki sa'y idüp ana dil-teşnegân-l seyr-i cemâl (Ahmed-i Nâmî: K: 11/9)

5. 4. Kıyamet Günü: Hadis-i şerifte nakledildiği üzere kıyamet günü Hz. Muhammed (SAV), "Yâ Rabbi, kalbinde hardal tanesi kadar imanı olanları Cennet'e koy" diyerek ümmetine şefaat edecektir. (Buhârî, Tevhîd 37) Kâtibzâde Sâkıb'ın bir naatında yer alan aşağıdaki beyitte de bu hadis-i şerife telmih yapılmakta ve şair Hz. Peygamber'in bir damla şefaatini arayacak olanların kıyamette bir an bile susuzluk çekmemeleri için dua etmektedir. Bu beyti naat-1 Nebî ile ilgili bölümde değil de kıyamet günü ile ilgili olan bu bölümde zikretmemizin sebebi ise teşnegî kelimesinin kıyamet günü ile ilişkilendirilmiş olmasıdır:

Katre-cûyı olan ol menba'-l cûd u keremün

Görmeye teşnegîl-i rûz-ı klyâmet bir ân (Kâtibzâde Sâkıb: K: 2/29)

Nâbî’nin Yûsuf Paşa çeşmesi için söylemiş olduğu tarih şiirinde teşnegî-i haşr kullanımı kıyamet gününün susuzluğunu ifade etmek için kullanılmıştır:

Vârid u sâdır içün âb-ı zülâl itdi sebîl

Getüre teşnegî-i haşrda râhına Hudâ (Nâbî: T: 102/4)

8 “Şüphesiz âlemlere bereket ve hidayet kaynağı olarak insanlar için kurulan ilk ev -mâbed- Mekke'deki -Kâbe-dir." (Âl-i İmrân 3/96) 
Kıyamet gününün susuzluğu aynı zamanda Hz. Peygamber' in yüzünü görmekten mahrum olmayı da ifade etmektedir:

Umduğum oldur ki rûz-i haşr mahrûm olmayam

Çeşme-i vaslın vire ben teşne-i dîdâre su (Fuzûlî: K: 3/32)

5. 5. Ehl-i Beyt/Kerbelâ: Peygamber torununun Kerbelâ'da günlerce susuz bırakılması, beraberindekiler ve kucağında küçük çocuğu Ali Asgar ile şehit edilişi, üzerinden yüzyıllar geçmiş olmasına rağmen Türk-İslam edebiyatında anılmaya devam edilmiştir. Yalnızca Şiî-Alevî edebiyatında değil Türk edebiyatının tamamında büyük yer edinmiş olan bu elim hadise ile ilgili kaleme alınmış manzum ve mensur eserler, edebiyatımızda büyük bir yere sahiptir. Teşne kelimesi de Hz. Hüseyin ve beraberindekilerin Kerbelâ'da 10 gün susuz bırakıldıktan sonra katledilmeleri dolayısıyla, tabii olarak Kerbelâ ve Hz. Hüseyin konulu şiirlerde sıkça kullanılmıştır. Kelimenin ilk mânâsı olan susuz, susamış olarak ifade edilen bu tâbir maktel, mersiye ve Kerbelâ konulu şiirlerde en elim hâliyle karşımıza çıkmaktadır.

Azmizâde Hâletî (v. 1631), Hasan Paşa'ya sunduğu kasidesinin son beytinde Kerbelâ'da dudakları susuzluktan kurumuş şehitlerin hakkı için, halkın imamı Hz. Hüseyin için, Resulullâh'ın yüzü suyu ve Kevser suyunun sâkîsi Hz. Ali için dua etmektedir:

Be-hakk-ı teşne-dil-i Kerbelâ imâm-ı enâm

Be-âb-ı rûy-ı Resûl ü be-sâki-i Kevser (Azmizâde Hâletî: K: 28/47)

Kânî (v. 1792) ise mersiyesinde Hz. Hüseyin'in, katledilişinden birkaç dakika önce, susuzluktan bitkin düşmüş ve yaralı bir hâlde Fırat nehrinin kıyısına vararak tam bir yudum su içecekken bir ok darbesi ile mübarek ağzından vurulması hadisesini konu almıştı:

'Adâvetün ne idi teşne-leb helâk itdün

Esirgedün suyını Kerbelâ'daki nehrün (Kânî: K: 45/4)

Gelibolulu Mustafa Âlî’nin Kerbelâ konulu bir gazelinde söylediği şu beyitte ise teşne, Kerbelâ şehitlerinin susuzluğunu kastetmekle birlikte onların aynı zamanda Allah yolunda can vermeyi arzu edişleri ve şehadet şerbetine susamış olduklarını da ifade etmektedir: 
Yazarsan Kerbelâ yazısınun müşkil belâsın yaz

Şehâdet şehdin içmiş teşne-diller mâ-cerâsın yaz (Gelibolulu Mustafa Âlî: $\mathrm{G}: 9 / 7)$

Nigâri de bazı beyitlerinde Kerbelâ şehitlerinden "teşnegân-1 Kerbelâ" şeklinde söz etmiştir:

Teşnegân-ı Kerbelâ 'aşkına bir devr it tamâm

Kâse-i ser-şârıla ger cânın ister bin sevâb (Nigârî: G: 57/3)

Rivâyet teşnegân-ı Kerbelâ'dan kilma ey râvî

Yanarız âteş-i hasretle zîrâ dâg-dârız biz (Nigârî: G: 279/8)

19. yüzy1l şairlerinden en çok Kerbelâ mersiyesi yazanlardan biri olan Şeref Hanım (v. 1861) da aşağıdaki beytinde Kevser suyunun sâkîsi olarak anılan Hz. Ali'nin oğlu Hz. Hüseyin'in dudakları kurumuş, susuz bir hâlde şehit edilişinden duyduğu üzüntüyü dile getirmiştir:

Sâkî-i Kevser' in evlâdı revâ mı a denî

Teşne-leb 'adne harâretle şitâbân olsun (Şeref Hanım: K: 16/18)

5. 6. Hz. Yûsuf: Dîvân şiirinde Hz Yûsuf'u konu edinen beyitlerde de teşne kelimesinin kullanıldığı görülmektedir. Sünbülzâde Vehbî (v. 1809), Y ûsuf k1ssasına yaptığı telmih ile kendini kuyuya düşmüş bir susuz olarak niteler:

Ey Yûsuf-ı gül-pîrehen olsun meded zülfün resen

Üftâde der-çâh-ı zekan dil-teşneem bî-dest ü pâ (Sünbülzâde Vehbî: G: 3/3)

\section{Ecel ile Kurulan İlişki}

Ecel "muayyen olan vade, ömrün sonu. İslâm dinine göre Allah tarafindan takdir edilen ecel ne ileri ne de geri alınabilir. Divân edebiyatında sevgilinin ayva tüyleri ile münasebeti olduğu düşünülür.” (Pala 2007: 133) Ecelin kaçınılmaz bir son oluşu, dahası Allah'ın takdir ettiği zamanda emrettiği şekilde gerçekleşecek olması dîvân şiirinde çeşitli mânâ çerçeveleri içerisinde kullanılmıştır.

Ahmed-i Nâmî' nin şu beytinde ölüm şerbetine ecelin susamış olması ise, bir taraftan ölümün Allah'ın bir emri olması dolayısıyladır. Diğer taraftan ise, bu fâni dünyanın derdini daha fazla çekmek istememek arzusuyla, ecel bile Hz. İsâ'nın hayat bahşeden nefesi dahi olsa bir gün ölmeyi diler: 
Şerbet-i mevte ecel teşne olur her nefesi

Rûh-bahş olsa ger enfâs-ı Mesîhâya göre (Ahmed-i Nâmî: G: 345/6)

Ecel sâkîsi elbette herkese ecel şerbetinden içirecektir. $\mathrm{O}$, bu dünya meclisinden hiç kimseyi susamış ve kurumuş dudaklarla geçirmez. Yani, hiç kimse bu dünyada bâkî kalmayacak, herkes elbet bir gün ecel şerbetine kanacaktır:

Bir kimseyi leb-teşne geçürmez su arar hep

Sâkî-i ecel herkese şerbet virecekdür (Kânî: G: 49/3)

Kâtibzâde Sâkıb ise bir gazelinde, önüne geleni affetmeyen keskin hançerin özünün, ölüm çeşmesinden gelen arzulu dalgalar olduğunu söylemektedir. Ecel nasıl kimseyi affetmeye muktedir değil ve vakti geldiğinde herkesin canını almakla mükellef ise, bu keskin hançer de ilhamını ondan almış, savaş meydanlarında düşmanın üzerine adeta dalga dalga ölüm salmıştır:

Mevc-i dil-teşnegî-i çeşme-i merg

Hançer-i âbdâra cevherdür (Kâtibzâde Sâkıb: G: 163/4)

\section{Belde ve Mekânlar Üzerinden Kurulan İlişki}

Teşne kelimesinin belde ve mekânlarla ilişkilendirilmesi birbirinden uzak açılarla gerçekleştirilmiş, şairin betimleme ve anlam dünyasına göre bir sistematiğe bağlanamayacak şekilde kullanılmıştır. Gerek bir yeri övmek gerek kuraklığından dem vurmak gibi maksatlarla kullanılan teşne tâbirine şiirlerde sıkça yer verilmiştir.

Kâmî Lâle Devri'nin en önemli aktörü olan Damad İbrahim Paşa'yı övdüğü terkib-bendinde kendisi tarafindan yaptırılmış olan Cedvel-i Sîm'in ancak saf ve tertemiz suyu istediğini söylemektedir. En şaşaalı dönemini III. Ahmed zamanında yaşamış olan Sadâbâd, yüzlerce köşk ve bahçeyle donatılmıştı. "Lale Devri’nin meşhur eğlence ve gezinti yerlerinden olan Kâğıthane'deki Sa'dabad'da inşa edilen çağlayanlardan sonra derenin bir bölümünün içi ve kenarları mermer kaplanarak düzenlenmiş ve bu kısma Cedvel-i Sim adı verilmiştir." (Uzun 1993: 215)

Cedvel-i Sim 'i ki dil-teşnesidür mâ-i ma 'în

Reşk ider hâk-i 'itırnâkine Bulgâr-zemîn (Kâmî: TB: II/1)

Şehrî (v. 1660) tarafindan yazılmış aşağıdaki beyit ise, Hicaz'ın suya hasret bölgelerine gönderme niteliği taşımaktadır. Hicaz kurak bir bölge olduğundan 
dolayı, susuzluk bu bölgede var olan bir mesele olarak yaşanagelmiştir. Coğrafî özellikleri ve iklimi her ne kadar çeşitlilik arz etse de kurak ve verimsiz arazilerin, çöllerin bol olduğu bu bölge, tarih boyunca çok kez suya hasret kalmıştır. Buradan mülhem olarak Şehrî bir beytinde şöyle demektedir:

Hayâl-i Âb-ı Hayât-ı lebünle 'ayş ideli

Serâba âb dirüz teşne-i Hicâz gibi (Şehrî: G: 131/2)

Celîlî (v. 1569) ise, teşne kelimesi ile Acem diyarının toprağının kuruluğundan bahsetmektedir:

Çü teşneydi hâk-i diyâr-ı 'Acem

Döküp Sürhser kanın itdi sebîl (Celilî: T: 5/3)

\section{8. İnsan Dışı Varlıkların Teşneliği}

Klasik şiirimizde özlemek, istemek ve susamak sadece kişiler için değil, cansız nesneler için de geçerlidir. Hüsn-i ta'lil, teşhis gibi edebî sanatlara başvurularak oluşturulan anlam dünyası etrafında zengin bir söz varlı̆ğ oluşturulmuştur. Teşne kelimesi de yalnızca bir kimseyi değil cansız varlıkların hâllerini de karşılamak üzere çeşitli varlıklarla bir arada karşımıza çıkmaktadır. Örneğin Kâtibzâde Sâkıb, şu beytinde mecaz yoluyla mağrifet pınarlarının âsîlere teşne olmasından söz etmektedir:

Çeşmesâr-ı magfiret 'âsîlere leb-teşnedür

Çeşm-i hasretdür habâb-ı âb ter-dâmân içün (Kâtibzâde Sâkıb: G: 452/6)

Behiştî (v. 1571) ise teşne sözü ile toprağın susuz ve kurumuş oluşunu ifade etmektedir:

Ben hakîre 'ârızun âbı ne yüzden suna câm

Hâk-i teşne çeşme-i hurşîdden alur mı kâm (Vizeli Behiştî: G: 334/1)

Klasik şiirimizde en sık kullanılan mazmunlardan biri de felektir. Dünya'nın, Güneş'in ve diğer tüm kozmik varlıkların daimî devirleri dîvân şiirinde bir sebebe veya sonuca bağlanmak suretiyle çokça kullanılmıştır. Fuzûlî’nin (v. 1556) bu beytinde felek, yani dünyadaki hadiseler kimin kanını dökerse o zaman kurumuş ve susamış olan toprak o kişinin kanını emecektir: 
Ehl-i zemâne kanina çok teşnedür zemîn

Kanın kimün dökerse felek ol zemân içer (Fuzûlî: G: 86/2)

Vecdî’de (v. 1599?) ise, güneşin parlak 1şı̆̆ının nemi alma özelliği üzerinde durulmuş ve güneşin gül suyunu kurutması çok susamış olduğuna bağlanmıştır:

Tolı gül-âb ile göricek gonca câmını

Nûş itdi çekdi teşne imiş mihr-i tâbdâr (Filibeli Vecdî: G: 12/4)

Nâbî'nin Edirne'deki Musahib Mustafa Paşa Çeşmesi için kaleme almış olduğu tarih şiirinde geçen beytinde, dünya teşne olduğu için bir iki kadeh uğruna devretmekte, susuzluktan bir an bile yerinde duramamaktadır:

Devr ider sanma teşnedür gerdûn

İ̧̧mek ister bir iki peymâne (Nâbî: T: 12/4)

Münîrî, bir münacatında dağların Allah'ın rahmet feyzine susadıkları için baş açık, kurak bir şekilde yüzlerini göğe doğru döndüklerini söyler. Dağların klasik şiirimizde daha çok dinî muhteva ile bağlantılı kullanıldığını ayrıca söylemek gereklidir. Bu durum şeklî özellikleri bakımından benzetme alanının, nüansının, anlam bağlantısının mahdûd oluşuna bağlanabilir. (Çavuşoğlu 1986: 4) Dîvân şiiirinde dağ bir güzellik unsuru olmanın ötesinde ilâhî mânâda bir ululuğu simgeler:

Yüzin tazarru'ile tutar göge baş açup

Bir katre feyz-i rahmetüne teşnedür cibāl (Münîrî: K: 1/34)

Münîrî ayrıca şarap sürahisinin teşneliğinden bahsetmekte ve bu sürahinin susuzluktan, yani içinde şarap bulunmamasından dolayı hasta göründüğünden de söz etmektedir:

Sâkîyâ nabz-ı sürâhîye el ur kim demidür

Teşne-dillikden olur nâ-geh o da haste-mizâc (Münîrî: G: 34/3)

Sünbülzâde Vehbî ise, sünbül bahçelerinin kuruduğunu, ancak yağmur bulutlarıyla değil âşığın göz yaşlarıyla sulanabileceğini söylemiştir:

Ebr-i tîre-rûy-ı gerdûnun degildir teşnesi

Vehbiyâ şâd-âb olur eşk ile sünbülzârımız (Sünbülzâde Vehbî: K: 65/16)

Teşneliğin kuvvetli istek mânâsında kullanıldığı bir diğer beyitte ise Bursalı İffet (v. 1840), şeker kamışının sevgilinin şeker gibi gülüşünü arzuladığını söylemektedir: 
Şekkerîn handesinün teşnesidir kand-i nebât

Nükhet-i hulkinun âşüftesidir 'anber-i hâm (Bursalı İffet: K: 1/22)

Ahmedî gonca-gül manzumunu teşne ile birlikte kullanarak içi yanıp susayan herkes gibi sevgilinin dudağının arzusuyla gönlünün sıkıştığını söylemektedir:

Lebünün şavkl-la gonca n'ola dil-teng itdi-y-se

Kamu teşne-ciger olan bulur mı âb-ı hayvânı (Ahmedî: K:71/14)

Tezkire-i Şuarâ-yı Mevleviyye yazarı Esrar Dede bir rubaisinde, gonca gül benzetmesini kullanarak hem susuzluğundan hem de tasavvufî mânâda Mevlevîlik ile ilişkisinden söz etmektedir:

Peymâne dönüp bezmde handân handân

Gül-gonce-i teşne açdı bustân bustân

Alay-ı safâ göründü leşker leşker

Dil-ber ser-i bezme geldi raksân raksân (Esrar Dede: R: 110)

Gelibolulu Mustafa Âlî ise, teşne redifli gazelinde ateşin susamasından dem vurmuştur. Su ateş için her ne kadar bir son olsa da ateş her hâlükârda susar:

'Iş̧̧un harâretinden oldum şarâba teşne

Âteş dahı olurmış devründe âba teşne (Gelibolulu Mustafa Âlî: G: 1316/1)

Kadı Burhâneddin'de derdin ilaç istemesini değil ilacın derde teşne olduğunu görmekteyiz. Zira dert olmazsa devâ da kıymetini kaybeder:

Derdüm oldur ki ben derdümi artuh dilerem

Derdüm oldur ki ana dârû-yı derman teşne (Kadı Burhâneddin: G: 1094/6)

Hayâlî Bey (v. 1556-57) susamış bir köpeğe su vermenin Allah katındaki büyük mükafatını bildiren hadis-i şerîfe (Buhârî, Şirb 9, Vudû 33, Mezâlim 23, Edeb 27) telmihte bulunarak şu beyti söylemiştir:

Leylînün kûyu itin teşne görüb vâdîde

Kâşe-i çeşmi sifâlinde suvarmış Mecnûn (Hayâlî Bey: G:40/4)

Dîvân şiirinde karşımıza çok sık çıkmayan bir hayal olarak Cennet'in insanlara teşne oluşunu da Nâbî’nin bir beytinde görmekteyiz:

Gülistân-ı cinân leb-teşne-i teşrîf-i insândur

Olan reh-zen bana bî-râhi-i nefs-i hasîsümdür (Nâbî: G: 132/3) 
Arpaeminizâde Mustafa Sâmî'de dalgaların, sevgilinin ayağını öpmeye istekli ve bu sebeple dudaklarının kurumuş olduğu görülmektedir:

Pâ-bûs-ı yâra teşne leb-i cûybârda

Ta 'kîb idüp biribirin itmez karâr mevc (Arpaeminizâde Mustafa Sâmî: G: 20/8)

Nev'îzâde Âtâyî’nin aşağıdaki beyti her ne kadar ok -yani silah- mefhumu etrafinda şekillenmiş olsa da teşne tâbiri mecazen de olsa sedefin inci vermek için suya ihtiyaç duyması üzerinden kullanıldığ 1 için bu bölümde zikretmeyi uygun bulduk.

Zahmumun azgin sulandursa nola peykânlarun

Katreye olur sadef ey dürr-i yektâ teşne-leb (Nev'îzâde Atayî: G: 14/2)

Kâmî'nin teşne-leb redifli gazelinde Güneş'in bir çiy tanesine susamış olduğunu, incinin bir damla suya muhtaç olduğunu, kadehin dudaklarının şaraba susamış olduğu görülmektedir:

Eşk-i hûn-âlûdumuz görmez o meh kim şeb-neme

Nice olmış âfitâb-ı zerre-perver teşne-leb (Kâmî: G: 13/3)

Her hazef âb içre ser-şâr-ı visâl-i ârẑิ

Katre-i nâ-çîzine ammâ ki gevher teşne-leb (Kâmî: G: 13/4)

Bezme gel ey mest-i nâzum Kâmi-i zâruñ gibi

Intizâr-ı la 'l-i mey-gûnunla sâgar teşne-leb (Kâmî: G: 13/5)

Cenâbî’nin (v. 1561-62) bir beytinde ise, kılıcın düşmanın kanına susadığ1 için teşne-leb şeklinde tarif edildiğini görüyoruz:

Teşne-lebdür hûn-ı hasma dem-be-dem şemşîrümüz

Togrulupdur almaga cân-l 'adûyı tîrümüz (Cenâbî: G: 129/1)

\section{Kitabet Sahası ile Kurulan İlişki}

Dîvân şiirinde bu tâbir yalnızca kişilerin iştiyakını dile getirmekle sınırlı kalmamış kitabet sahasında da şairlerin meramını anlatmalarında bir vasıta olmuştur. Nâ'ilî bir beytinde sözünü âb-1 hayâta benzetmiş ve kaleminden sızan damlaya âb-1 zülâlin susamış olduğunu söylemiştir: 
Garka virdi felegi âb-ı hayât-ı suhenüm

Reşha-i kilküme leb-teşne yine âb-l zülâl (Nâ'ilî-i Kadim: K: 12/77)

Ta'cizâde Ca'fer Çelebi (v. 1515) ise kamış kalemin ucuna açılan ince yarığın teşnelikten olduğunu söylemiştir. Uğurlu haberi yazan kalemin dili, cengin vasfinı anlatmaya o kadar heveslidir ki çatlamıştır:

Şol kadar dil-teşnedür yazmaga rezmün vaşfinı

Kim yarılmışdur zebân-ı hâme-i ferruh-peyâm (Ta'cizâde Ca'fer Çelebi: $\mathrm{K}: 14 / 83)$

Revânî (v. 1523-24) şiirinin susamış, kurumuş gönüllere yardım ettiğini ve bu akıcı sözünün adeta bir içim suya benzediğini söylemektedir:

Çok teşne dillere meded ider bu şi'r-i ter

Bu nazm-ı âbdâr hemân bir içim sudur (Revânî: G: 136/5)

Revânî Sultan Bayezid'i (1481-1512) methettiği bir kasidesinde ise şöyle demektedir: Benim şiirimin pınarına cihan susamış, kalemimin lülesinden âb-1 zülâl aksa bunda şaşılacak ne var?

Oldı ser-çeşme-i nazmuma cihân çün teşne

Lüle-i hâmem akıtsa ne 'aceb âb-l zülâl (Revânî: K: 17/48)

Nâbî'nin Sadrazam Rami Muhammed Paşa’ya sunduğu kasidesinde ise zemzemin divitteki suya, yani şiiri yazan mürekkebe teşne olduğu görülmektedir:

Çâkdur hasret-i şakk-ı kalem ile mîzâb

Teşnedür çâh-ı devâtındaki âba zemzem (Nâbî: K: 15/64)

Nef'î (v. 1635) ise Nasuh Paşa için yazdığı kasidesinin fahriye bölümünde Cennet'teki Kevser ve Tesnim sularının, onun su gibi olan şiirine susadığını yazmıştır:

Nihâl-i hâmeme dilbeste Sidre vü Tûbâ

Zülâl-i nazmıma leb-teşne kevser ü tesnîm (Nef'î: K: 32/45)

Sâkıb Dede gönlü yanmış ve arzulu olanı suya ancak taze, yeni söylenmiş şiirin kandırabileceğini, Cennet’ten söz eden irfanın Kevser suyunun da bu olduğunu söylemiştir. Onun için yeni sözler söylemek, cana can katan ve aktıkça akan bir Kevser suyuna benzemektedir: 
Sîr-âb iderse teşne-dili şi 'r-i ter ider

Cennet-serâ-yı ma 'rifetün Kevseri budur (Sâkıb Dede: G: 55/18)

\section{Sonuç}

Teşne kelimesi sözlüklerde en çok "susuz”, "susamış", "istekli” anlamlarında yer almaktadır. Klasik edebiyatımızda ise, kelime su ile ilişkili olarak susamak, susuzluktan kurumak, bir şeyi çok istemek, âb-1 hayâtı arzulamak gibi anlamların yanında, şairlerin meylettikleri birbirinden farklı sahalar, iştiyaklar ve gelenekler neticesinde farklı anlamlara bürünmüştür.

$\mathrm{Bu}$ çalışma ile sözlüklerde yer alan anlamları dışında "teşne-dil" kelimesinin, gönlü coşturacak ve ona canlılık verecek şeylerden mahrum kalması anlamına da dolaylı olarak ulaşıılmıştır.

Çalışma esnasında dîvânında teşne kelimesini kullanan 111 şair ve bu şairlere ait toplam 1225 beyit tespit edilmiştir. Ayrıca teşne kelimesinin redif olarak kullanıldığ 13 adet şiire rastlanmıştır. Şiirlerinde teşne kelimesini en çok kullanan şairler sırasıyla Ahmedî(66), Gelibolulu Mustafa Âlî(59), Kadı Burhaneddin(54) ve Kâtibzâde Sâkıb(52) olarak tespit edilmiştir.

Teşne kelimesi şiirlerde âb-1 hayat ile olan ilişkisi üzerinden Hızır ve İskender ile; su ile olan ilişkisi üzerinde susuzluk, kurumak ve hasta birinin çektiği susuzluk ile ilişkilendirilmiştir. Ayrılıktan dolayı sevgilinin düştüğü durumu tasvir etmede, gönlün hâllerini ifadede kullanılmış; âşı̆̆ın sevgilinin cevr ü cefâsını arzulaması ile ilişkilendirilmiştir. İslâmî içerikli şiirlerde de sıklıkla başvurulan teşne Allah'ın rahmetini dilemek, tasavvufî bir açlık, Hz. Peygamber'in şefaatine nâil olma arzusu, kıyamet gününde duyulacak olan susuzluk, Kevser suyunun sâkîsi olan Hz. Ali, Kerbelâ vâkıası, Hz. Yûsuf kıssası, ecelin mutlaka insanları gelip bulacak olması ile ilişkilendirilmiştir. Ayrıca şairlerin anlam dünyalarında belde ve mekânlar için; insan dışında toprak, şarap kadehi, güneş, gül gibi mefhumlar için; kitabet sahasında da kâğıdın mürekkebe teşne olması, kamış kalemin kuruluğu gibi mânâlarda da kullanılmıştır.

Makale hazırlanırken mümkün olduğunca çok şiire ulaşarak şairlerin bu kelime etrafında oluşturdukları anlam dünyasının bir haritası çıkarılmaya çalışılmıştır. Ancak inceleme fırsatı bulunamayan ve teşne kelimesi ile oluştu- 
rulmuş farklı anlam zenginliklerinin de olabileceği muhakkaktır. Ayrıca makale hazırlanırken sadece dîvânlarla sınırlı bir inceleme yapıldığını ve farklı türdeki eserlerde farklı benzetmelerin de ortaya çıkabileceğini belirtmek gerekir.

Çalışma esnasında klasik şairlerimizin muhayyilesinde oluşanları ifade ederken başvurdukları benzetmelerin zenginliği içerisinde, teşne kelimesi etrafinda nasıl bir benzetme dünyası oluşturduklarını ortaya koymaya çalışılmıştır. Böylece dîvân şiirimizdeki ifade zenginliğinin bir iz düşümü ve şairlerin hayal dünyasının keşfedilişi ile dönemin sosyo-kültürel dokusunun da daha iyi anlaşılması adına bir basamak teşkil etmesi amaçlanmıştır. 


\section{Kaynakça}

Ahmet Vefik Paşa (2000), Lehçe-i Osmânî, Haz. Recep Toparlı, Ankara: TDK Yayınları.

Akdoğan, Yaşar, Ahmedî Dîvânı, https://ekitap.ktb.gov.tr/Eklenti/10591,ahmedidivaniyasarak doganpdf. pdf?0

(E.T. 11.02.2020)

Akkuş, Metin (1991), Nef'î Sanatı ve Türkçe Dîvânı (İnceleme-Karşılaştırmalı Metin), Erzurum: Atatürk Üniversitesi, Sosyal Bilimler Enstitüsü. (Doktora Tezi)

Aksoyak, İsmail Hakkı (2018), Gelibolulu Mustafa Âlî Dîvânı, https://ekitap.ktb.gov.tr/ Eklenti/58695,gelibolulu-mustafa-ali-divanipdf.pdf?0

(E.T. 26.12.2019)

Akyüz, Kenan, Beken, Süheyl, Cunbur, Müjgan, Yüksel, Sedit (1958), Fuzûlî Türkçe Divan, Ankara: TTK Basımevi.

Arı, Ahmet (2003), Mevlevîlikte Bir Hânedanlık Kurucusu Sâkıb Dede ve Dîvânı, Ankara: Akçă̆ Yayınları.

Arslan, Mehmet (2002), Şeref Hanım Dîvânı, İstanbul: Kitabevi Yayınları.

Arslan, Mehmet (2005), Bursalı Iffet Divanı, İstanbul: Kitabevi Yayınları.

Avşar, Ziya (2017), Revânî Dîvânı, https://ekitap.ktb.gov.tr/Eklenti/56143,revani-divanipdf.pdf?0 (E.T. 21.01.2020)

Aydemir, Yaşar (2007), Ravzî Divanı, Ankara: Birleşik Kitabevi Yayınları.

Aydemir,Yaşar(2018), RamazanBehiştîD̂̂vânı, https://ekitap.ktb.gov.tr/Eklenti/56445,ramazanbehisti-divanipdf.pdf?0

(E.T. 14.01.2020)

Bilgin, Azmi (2017), Nigârî Dîvânı, https://ekitap.ktb.gov.tr/Eklenti/55757,nigari-divanipdf.pdf?0 (E.T. 23.01.2020)

Bilkan, Ali Fuat (1993), Nâbî’nin Türkçe Dîvânı (Karşılaştırmalı Metin), Ankara: Gazi Üniversitesi, Sosyal Bilimler Enstitüsü. (Doktora Tezi)

Cebecioğlu, Ethem (2005), Tasavvuf Terimleri ve Deyimleri Sözlüğü, İstanbul: Anka Yayınları.

Çavuşoğlu, Mehmed (1986), “Divan Şiiri”, Türk Dili, LII, S. 415-416-417.

Demirel, Şener (1999), Şehri (Malatyalı Ali Çelebi) hayatı, sanatı, divanının tenkitli metni ve tahlili, Elazığ: Fırat Üniversitesi, Sosyal Bilimler Enstitüsü. (Doktora Tezi)

Doğan, Mehmet (2011), “Gönül”, Doğan Büyük Türkçe Sözlük, C. 24, Ankara: Yazar Yayınları.

Ergin, Muharrem (1980), Kadı Burhaneddin Dîvânı, İstanbul: İ̈̈ Edebiyat Fakültesi Yayınları.

Ersoy, Esen (2017), Münîrî Dîvânı, https://ekitap.ktb.gov.tr/Eklenti/56095,muniri-divanipdf.pdf?0 (E.T. 20.01.2020) 
Erünsal, İsmail E. (1983), The Life and Works of Tâcî-zâde Ca'fer Çelebi, With A Critical Edition of His Dîvân, İstanbul: İstanbul Üniversitesi Yayınları.

Uzun, Mustafa İsmet (1993), “CEDVEL” https://islamansiklopedisi.org.tr/cedvel\#2-sant (E.T.10.12.2019)

İpekten, Haluk (2019), Nâ'ilî-i Kadim Divânı, https://ekitap.ktb.gov.tr/Eklenti/67155,naili-ikadim-divanipdf.pdf?0

(E.T. 12.01.2020)

İsen, Mustafa (2019), Hamâmîzâde İhsan, https://ekitap.ktb.gov.tr/Eklenti/64194,hamamizadeihsan-divanipdf.pdf?0,

(E.T. 13.02.2020)

Karaköse, Saadet (1994), Nev'îzâde Atâŷ̂ Dîvânı (Kısmî Tahlil-Metin), Malatya: İnönü Üniversitesi, Sosyal Bilimler Enstitüsü. (Doktora Tezi)

Karaköse, Saadet (2017), Sa 'id Giray Dîvânı, https://ekitap.ktb.gov.tr/Eklenti/55754,saidgiray-divanipdf.pdf?0

(E.T. 13.02.2020)

Kasır, Hasan Ali (1996), Esrâr Dede Hayatı, Edebî Kişiliği ve Divanı'nın Karşılaştırmalı Met$n i$, Erzurum: Atatürk Üniversitesi, Sosyal Bilimler Enstitüsü. (Doktora Tezi)

Kavruk, Hasan, Selçuk, Bahir (2017), Filibeli Vecdî Dîvânı, https://ekitap.ktb.gov.tr/Eklenti/55912, filibeli-vecdi-divanipdf.pdf?0

(E.T. 15-01-2020)

Kaya, Bayram Ali, Azmîzâde Haletî Dîvânı, https://ekitap.ktb.gov.tr/Eklenti/56159,azmizade-haleti-divanipdf.pdf?0

(E.T. 11.02.2020)

KAZAN NAS, Şevkiye, Celilî Divânı, https://ekitap.ktb.gov.tr/Eklenti/59375,celili-divanipdf.pdf?0 (E.T. 12.02.2020)

Keklik, Murat (2014), Üsküplü İshak Çelebi Divan (Metin-Çeviri-Açıklamalar-Dizin), Bişkek: Kırgızistan-Türkiye Manas Üniversitesi, Sosyal Bilimler Enstitüsü. (Doktora Tezi)

Kesik, Beyhan (1996), Cenâbî Paşa Dîvân (Hayatı, Edebî Kişiliği, Divanı'nın Karşılaştırmalı Metni), Elazığ: Fırat Üniversitesi, Sosyal Bilimler Enstitüsü. (Yüksek Lisans Tezi)

Kırbıyık, Mehmet (2017), Kâtibzâde Sâkıb Dîvânı, https://ekitap.ktb.gov.tr/Eklenti/56426,katibzade-sakib-divanipdf.pdf?0

(E.T. 15.01.2020)

Kurtoğlu, Orhan, Lebîb Dîvânı, https://ekitap.ktb.gov.tr/Eklenti/55756,lebib-divanipdf.pdf?0

(E.T. 14.01.2020)

Kutlar Oğuz, Fatma Sabiha, Arpaemînizâde Mustafa Sâmî Dîvânı, https://ekitap.ktb.gov.tr/ Eklenti/56084,arpaeminizade-mustafa-sami-divanipdf.pdf?0

(E.T. 31.01.2020) 
Küçük, Sabahattin, Bâkî Dîvânı, https://ekitap.ktb.gov.tr/Eklenti/10596,bakidivanisabahattink ucukpdf.pdf?0

(E.T. 11.01.2020)

Levend, Agâh Sirrı (1984), Divan Edebiyatı: Kelimeler ve Remizler, Mazmunlar ve Mefhumlar, İstanbul: Enderun Kitabevi.

Macit, Muhsin (2018), Erzurumlu Zihnî Dîvânı, https://ekitap.ktb.gov.tr/Eklenti/58638, erzurumlu-zihni-divanipdf.pdf?0

(E.T. 01.01.2020)

Mermer, Ahmet (2004), Kütahyalı Rahimî ve Dîvânı, İstanbul: Sahhaflar Kitap Sarayı Yayınları.

Mütercim Âsım Efendi (2009), Burhân-ı Katı, İstanbul, Türk Dil Kurumu Yayınları.

Onay, Ahmet Talat (2014), Açıklamalı Dîvân Şiiri Sözlüğü, Haz. Cemal Kurnaz, Ankara: Kurgan Edebiyat Yayınları.

Pakalın, Mehmet Zeki(1993), Osmanlı Tarih Deyimleri ve Terimleri Sözlüğ̈̈, C.1, Ankara: MEB Yayınları.

Pala, İskender (2007), Divan Edebiyatı Antolojisi, İstanbul: Kap1 Yayınları.

Sefercioğlu, M.Nejat (2001), Nev'î Dîvânının Tahlili, Ankara: Akçağ Yayınları.

Sofuoğlu, Mehmed (1987), Sahîh-i Buhâri ve Tercemesi, İstanbul: Ötüken Yayınları.

Steingass, Francis (1998), A Comprehensive Persian-English Dictionary, Lebanon: Typopress.

Şemseddin Sâmî (2009), Kâmûs-ı Türkî, İstanbul: Çağrı Yayınları.

Şükun, Ziya (1996), Farsça-Türkçe Lûgat Gencine-i Güftâr Ferheng-i Ziyâ, C.I-II İstanbul: Milli Eğitim Bakanlığı Yayınları.

Tâhirü'l-Mevlevî (1994), Edebiyat Lugatı, Haz. Kemâl Edib Kürkçüoğlu, İstanbul, Enderun Kitabevi.

Tanrıbuyurdu, Gülçin (2012), Mu'îdî Dîvân (Metin-Çeviri), Kocaeli: Kocaeli Üniversitesi, Sosyal Bilimler Enstitüsü. (Doktora Tezi)

Tarlan, Ali Nihad (1945), Hayâlî Bey Dîvânı, İstanbul: Bürhâneddin Erenler Matbaası.

Tarlan, Ali Nihad (2004), Şeyhî Dîvânı'nı Tetkik, Ankara: Akçağ Yayınları.

Tarlan, Ali Nihad (2018), Fuzûlî Dîvânı Şerhi, Ankara: Akçağ Yayınları.

Uludağ, Süleyman (1989), “ÂL-i ABÂ” https://islamansiklopedisi.org.tr/al-i-aba

(E.T.26.01.2020)

Uludağ, Süleyman (2001), Tasavvuf Terimleri Sözlüğü, İstanbul: Kabalcı Yayınevi.

Üst, Sibel (2018), Edirneli Nazmî Divant, https://ekitap.ktb.gov.tr/Eklenti/57766,edirnelinazmi-divanipdf.pdf?0

(E. T. 29.12.2019) 
Yazar, İlyas (2010), Kânî Dîvânı, İstanbul: Libra Yayıncılık.

Yazıcı, Gülgün Erişen (2017), Kâmî Dîvânı, https://ekitap.ktb.gov.tr/Eklenti/55977,kami-divani-pdf.pdf?0 (E.T. 09.01.2020)

Yenikale, Ahmet (2017), Ahmed Nâmî Dîvânı, https://ekitap.ktb.gov.tr/Eklenti/ 56192,ahmed-nami-divanipdf.pdf?0 (E.T.11.02.2020)

Yenikale, Ahmet (2017), Sünbülzâde Vehbî Dîvânı, https://ekitap.ktb.gov.tr/Eklenti/56212, sunbulzade-vehbi-divanipdf.pdf?0 (E.T. 31.01.2020)

Zavotçu, Gencay (2018), Klasik Türk Edebiyatı Sözlüğü, İzmit: Umuttepe Yayınları.

Zülfe, Ömer (2009), Yakîn̂̂ Dîvân (Inceleme-Metin ve Çeviri-Açıklamalar-Sözlük), http://docs. neu.edu.tr/library/nadir_eserler_el_yazmalari/Edebiyat/DIVANLAR/yakini_divani.pdf (E.T. 21.02.2020) 